\title{
JURNAL HARIAN/MINGGUAN
}

$\begin{array}{ll}\text { Nama Mahasiswa } & : \text { Novi Ariska } \\ \text { No. STB/NIRM } & : 9173770410045 \\ \text { Desa / Posko } & : \text { Balang Baru } \\ \text { Kecamatan } & \text { : Tarowang } \\ \text { Kabupaen } & \text { : Jeneponto }\end{array}$

\begin{tabular}{|c|c|c|c|c|c|c|c|}
\hline No & Minggu ke- & Hari / Tgl & Jam & Jenis Kegiatan & Lokasi & Yang Terlibat & Hasil \\
\hline \multirow[t]{6}{*}{1} & \multirow[t]{11}{*}{ I (Pertama } & \multirow{2}{*}{$\begin{array}{c}\text { Selasa } \\
15 \text { September } \\
2020\end{array}$} & $08.00-10.00$ & $\begin{array}{c}\text { Pelepasan Peserta } \\
\text { KKLP }\end{array}$ & $\begin{array}{c}\text { Kampus STIE STKIP } \\
\text { YAPTI } \\
\text { JENEPONTO }\end{array}$ & $\begin{array}{c}\text { Panitia } \\
\text { Pelaksana, } \\
\text { Dosen } \\
\text { Pembimbing } \\
\text { Dan Peserta } \\
\text { KKLP } \\
\end{array}$ & $\begin{array}{l}\text { untuk mengetahui } \\
\text { Tempat KKLP }\end{array}$ \\
\hline & & & $12.00-02.30$ & $\begin{array}{c}\text { Penerimaan pesrta } \\
\text { KKLP ke kepala Desa } \\
\text { dan Dosen Pembimbing }\end{array}$ & $\begin{array}{c}\text { Kantor Desa Balang } \\
\text { Baru }\end{array}$ & Peserta KKLP & $\begin{array}{c}\text { Peserta KKLP saling } \\
\text { mengenal dengan Kepala } \\
\text { Desa dan diterima } \\
\text { dengan baik }\end{array}$ \\
\hline & & \multirow[b]{2}{*}{$\begin{array}{c}\text { Rabu } \\
\text { 16 September } \\
2020\end{array}$} & $07.20-08.35$ & $\begin{array}{l}\text { Membersihkan posko } \\
\text { Desa Balang Baru }\end{array}$ & Lingkungan Posko & Peserta KKLP & - \\
\hline & & & $09.00-11.30$ & $\begin{array}{l}\text { Observasi/survey } \\
\text { Lapangan KKLP }\end{array}$ & $\begin{array}{l}\text { Dusun Bonto Manai } \\
\text { Dusun Bonto Masugi }\end{array}$ & Peserta KKLP & $\begin{array}{c}\text { Peserta KKLP } \\
\text { berinterakasi langsung } \\
\text { dengan masyarakat dan } \\
\text { peserta KKLP mendapat } \\
\text { informasi mengenai } \\
\text { kondisi masyarakat di } \\
\text { Desa Balang Baru }\end{array}$ \\
\hline & & \multirow{3}{*}{$\begin{array}{l}\text { Kamis } \\
17 \text { September } \\
2020\end{array}$} & $07.20-08.35$ & $\begin{array}{l}\text { Membersihkan posko } \\
\text { Desa Balang Baru }\end{array}$ & Lingkungan Posko & Peserta KKLP & - \\
\hline & & & $09.00-11.30$ & $\begin{array}{l}\text { observasi / survey } \\
\text { Lapangan KKLP }\end{array}$ & $\begin{array}{c}\text { Dusun Camba } \\
\text { Lompoa } \\
\text { Dusun Bonto Baru }\end{array}$ & Peserta KKLP & $\begin{array}{c}\text { Peserta KKLP } \\
\text { berinterakasi langsung } \\
\text { dengan masyarakat dan } \\
\text { peserta KKLP mendapat } \\
\text { informasi mengenai } \\
\text { kondisi masyarakat di } \\
\text { Desa Balang Baru }\end{array}$ \\
\hline & & & $20.00-21.30$ & $\begin{array}{c}\text { membahas hasil survey } \\
\text { Desa Balang Baru }\end{array}$ & Posko KKLP & Peserta KKLP & - \\
\hline & & \multirow{2}{*}{$\begin{array}{c}\text { Jum'at } \\
18 \text { September } \\
2020\end{array}$} & $07.00-08.30$ & $\begin{array}{c}\text { Membersihkan Posko } \\
\text { Desa Balang Baru }\end{array}$ & Desa Balang Baru & Peserta KKLP & - \\
\hline & & & $08.23-11.15$ & $\begin{array}{l}\text { Rapat Pemantapan } \\
\text { Program Kerja }\end{array}$ & $\begin{array}{c}\text { Kampus STIE/STKIP } \\
\text { YAPTI }\end{array}$ & $\begin{array}{l}\text { Kordes, } \\
\text { Sekretaris, } \\
\text { Bendahara }\end{array}$ & - \\
\hline & & $\begin{array}{l}\text { Sabtu } \\
\text { 19 September } \\
2020\end{array}$ & $08.00-11.30$ & $\begin{array}{c}\text { membersihkan Tempat } \\
\text { Wisata Dalam Rangka } \\
\text { Hari Kebersihan } \\
\text { Sedunia }\end{array}$ & $\begin{array}{c}\text { Tempat Wisata Hutan } \\
\text { Mangrove }\end{array}$ & $\begin{array}{c}\text { TNI, POLRI, } \\
\text { Dishub, Dinas } \\
\text { Kesehatan, } \\
\text { Dinas } \\
\text { Peberdayaan } \\
\text { Lingkungan } \\
\text { Dan } \\
\text { masyarakat, } \\
\text { Anggota } \\
\text { Pramuka, } \\
\text { Peserta KKLP } \\
\text { Dan Warga } \\
\text { Setempat }\end{array}$ & $\begin{array}{c}\text { Membuat Lingkungan } \\
\text { tempat wisata Menjadi } \\
\text { Bersih }\end{array}$ \\
\hline & & $\begin{array}{c}\text { Minggu } \\
\text { 20 September } \\
2020 \\
\end{array}$ & $13.00-17.00$ & Istirahat & Dusun Bonto Masugi & Peserta KKLP & $\begin{array}{c}\text { Membuat Tempat Wisata } \\
\text { Menjadi Bersih }\end{array}$ \\
\hline & II (kedua) & $\begin{array}{c}\text { Senin } \\
21 \text { September } \\
2020\end{array}$ & $06.30-07.35$ & $\begin{array}{c}\text { Membersihkan Posko } \\
\text { dan daerah sekitar } \\
\text { Posko }\end{array}$ & Lingkungan Posko & Peserta KKLP & $\begin{array}{c}\text { Membuat Halaman } \\
\text { posko dan sekitar posko } \\
\text { menjdi bersih }\end{array}$ \\
\hline
\end{tabular}




\begin{tabular}{|c|c|c|c|c|c|c|}
\hline & & $20.16-21.54$ & $\begin{array}{l}\text { pembuatan surat } \\
\text { undangan untuk } \\
\text { seminar desa }\end{array}$ & $\begin{array}{l}\text { Dusun Bonto Manai } \\
\text { Dusun Bonto Masugi } \\
\text { Dusun Camba } \\
\text { Lompoa } \\
\text { Dusun Bonto Baru }\end{array}$ & Peserta KKLP & - \\
\hline & $\begin{array}{c}\text { Selasa } \\
22 \text { September } \\
2020 \\
\end{array}$ & - & Istirahat & Dusun Bonto Masugi & Peserta KKLP & - \\
\hline & $\begin{array}{l}\text { Rabu } \\
23 \text { September } \\
2020\end{array}$ & 09.00-09.30 & $\begin{array}{l}\text { Pembangian undangan } \\
\text { seminar kesetiap Dusun } \\
\text { didesa Balang Baru }\end{array}$ & $\begin{array}{l}\text { Dusun Bonto Manai } \\
\text { Dusun Bonto Masugi } \\
\text { Dusun Camba } \\
\text { Lompoa } \\
\text { Dusun Bonto Baru }\end{array}$ & Peserta KKLP & - \\
\hline & $\begin{array}{l}\text { Kamis } \\
\text { 24 September } \\
2020\end{array}$ & $10.00-12.10$ & $\begin{array}{c}\text { Mengadakan seminar } \\
\text { Desa }\end{array}$ & $\begin{array}{c}\text { Kantor Desa Balang } \\
\text { Baru }\end{array}$ & $\begin{array}{c}\text { Seluruh } \\
\text { Peserta KKLP, } \\
\text { Kepala Desa } \\
\text { Beserta } \\
\text { seluruh } \\
\text { jajarannya dan } \\
\text { Masyarakat } \\
\text { Desa Balang } \\
\text { Baru }\end{array}$ & $\begin{array}{c}\text { Disepakatinya beberapa } \\
\text { Program Kerja KKLP } \\
\text { Desa Balang Baru yakni } \\
\text { Proker Fisik dan Non } \\
\text { Fisik }\end{array}$ \\
\hline & $\begin{array}{l}\text { Jum'at } \\
25 \text { September } \\
2020\end{array}$ & $08.00-10.00$ & $\begin{array}{l}\text { Melakukan jum'at } \\
\text { bersih }\end{array}$ & $\begin{array}{l}\text { Masjid Ar - Rahman } \\
\text { Al Mu'minim }\end{array}$ & Peserta KKLP & $\begin{array}{l}\text { membuat masjid terlihat } \\
\text { bersih dan nyaman untuk } \\
\text { dipakai beribadah }\end{array}$ \\
\hline & $\begin{array}{c}\text { Sabtu } \\
26 \text { September } \\
2020 \\
\end{array}$ & - & Istirahat & Dusun Bonto Masugi & Peserta KKLP & - \\
\hline & $\begin{array}{c}\text { Minggu } \\
27 \text { September } \\
2020\end{array}$ & $08.00-09.25$ & melakukan Baksos & Dusun Manai & $\begin{array}{l}\text { Peserta KKLP } \\
\text { dan warga } \\
\text { Dusun }\end{array}$ & $\begin{array}{l}\text { Membuat dusun Bonto } \\
\text { Manai terlihat bersih }\end{array}$ \\
\hline \multirow[t]{9}{*}{ III (Ketiga) } & $\begin{array}{c}\text { Senin } \\
\text { 28 September } \\
2020\end{array}$ & - & Istirahat & Dusun Bonto Masugi & Peserta KKLP & - \\
\hline & $\begin{array}{c}\text { Selasa } \\
\text { 29 September } \\
2020\end{array}$ & $09.00-12.00$ & $\begin{array}{l}\text { ikut serta dalam } \\
\text { musrembang di desa } \\
\text { Balang Baru }\end{array}$ & $\begin{array}{c}\text { Kantor Desa Balang } \\
\text { Baru }\end{array}$ & $\begin{array}{l}\text { Kepala Desa, } \\
\text { staff Desa } \\
\text { Balang baru, } \\
\text { Peserta KKLP } \\
\text { \& Masyarakat }\end{array}$ & - \\
\hline & \multirow{2}{*}{$\begin{array}{c}\text { Rabu } \\
\text { 30 September } \\
2020\end{array}$} & 08.00-09.00 & $\begin{array}{c}\text { melakukan perkenalan } \\
\text { disetiap sekolah Dasar } \\
\text { yang ada didesa balang } \\
\text { baru }\end{array}$ & $\begin{array}{l}\text { SDI } 225 \text { Bonto } \\
\text { Masugi } \\
\text { SDN No } 263 \text { Bonto } \\
\text { Baru } \\
\text { SD INP } 119 \text { Bontowa }\end{array}$ & Peserta KKLP & - \\
\hline & & $11.00-12.00$ & $\begin{array}{l}\text { Membeli bahan baku } \\
\text { untuk pelaksanaan } \\
\text { program fisik }\end{array}$ & $\begin{array}{l}\text { Pasar tarowang dan } \\
\text { pasar Kota Bantaeng }\end{array}$ & Peserta KKLP & $\begin{array}{l}\text { Tersedianya bahan baku } \\
\text { untuk Program fisik }\end{array}$ \\
\hline & \multirow{2}{*}{$\begin{array}{c}\text { kamis } \\
1 \text { Oktober } 2020\end{array}$} & $08.30-10.00$ & $\begin{array}{c}\text { Mengajar Di SDI } 225 \\
\text { Bonto Masugi }\end{array}$ & Dusun Bonto Masugi & Peserta KKLP & - \\
\hline & & $16.30-17.00$ & $\begin{array}{l}\text { Membuat Tempat } \\
\text { Sampah }\end{array}$ & Dusun Bonto Masugi & Peserta KKLP & - \\
\hline & \multirow{2}{*}{$\begin{array}{c}\text { Jumat } \\
2 \text { Oktober } 2020\end{array}$} & $08.00-10.00$ & $\begin{array}{l}\text { Melakukan jum'at } \\
\text { bersih }\end{array}$ & $\begin{array}{l}\text { masjid Ar - Rahman } \\
\text { Al Mu'minim }\end{array}$ & Peserta KKLP & $\begin{array}{l}\text { membuat masjid terlihat } \\
\text { bersih dan nyaman untuk } \\
\text { dipakai beribadah }\end{array}$ \\
\hline & & $16.30-17.15$ & $\begin{array}{l}\text { Membuat Tempat } \\
\text { Sampah }\end{array}$ & Dusun Bonto Masugi & Peserta KKLP & - \\
\hline & $\begin{array}{c}\text { Sabtu } \\
3 \text { Oktober } 2020\end{array}$ & $09.00-10.30$ & $\begin{array}{l}\text { Mengajar Di SDN No } \\
263 \text { Bonto Baru }\end{array}$ & Dusun Bonto Baru & Peserta KKLP & - \\
\hline
\end{tabular}




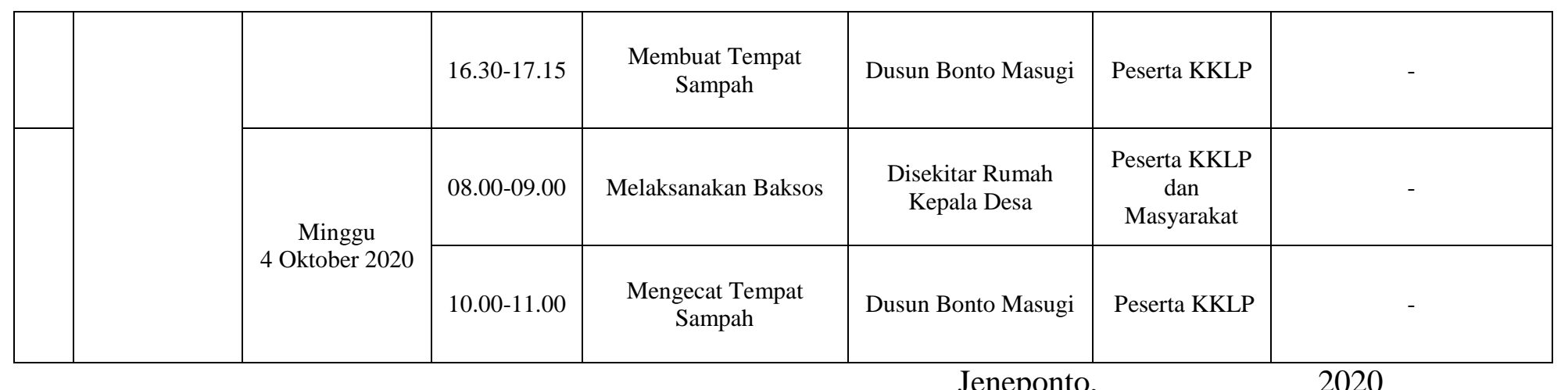

Kepala Desa Balang Baru

Peserta KKLP

$\underline{\text { Darman Patta }}$

$\underline{\text { Novi Ariska }}$

Mengetahui,

Dosen Pembimbing

\section{$\underline{\text { Rahim Sila, S.Pd, M.M }}$}

